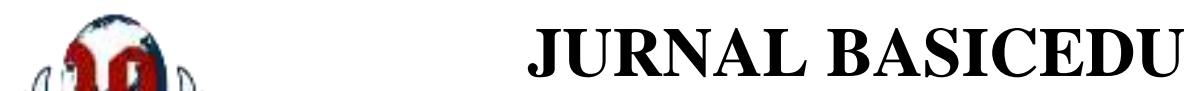

Volume 6 Nomor 1 Tahun 2022 Halaman 1116 - 1124

Research \& Learning in Elementary Education

https://jbasic.org/index.php/basicedu

$P \frac{A H L A M A N}{A H A}$

\title{
Pengaruh Kompetensi Pedagogik dan Profesional Guru Terhadap Motivasi Belajar Peserta Didik Sekolah Dasar
}

\author{
Krisnawati $^{1 凶}$, Siti Yulaeha ${ }^{2}$, Ketut Budiastra ${ }^{3}$ \\ Universitas Terbuka, Indonesia ${ }^{1,3}$, SMP Negeri 9 Magelang, Indonesia ${ }^{2}$ \\ E-mail: $\underline{\text { krisnafreya@gmail.com }}^{1}$, yulaeha@ gmail.com² ${ }^{2}$, budiastra@ecampus.ut.ac.id ${ }^{3}$
}

\begin{abstract}
Abstrak
Penelitian ini bertujuan untuk (1) menganalisis pengaruh kompetensi pedagogik terhadap motivasi belajar peserta didik kelas V di Kecamatan Jumo Kabupaten Temanggung, (2) menganalisis pengaruh kompetensi profesional terhadap motivasi belajar peserta didik kelas V di Kecamatan Jumo Kabupaten Temanggung, dan (3) menganalisis pengaruh kompetensi pedagogik dan profesional terhadap motivasi belajar peserta didik kelas V di Kecamatan Jumo Kabupaten Temanggung.Jenis penelitian ini menggunakan pendekatan penelitian kuantitatif. Populasi dalam penelitian ini adalah seluruh peserta didik kelas V SD di Kecamatan Jumo Kabupaten Temanggung Tahun 2020/2021. Sampel dalam penelitian ini menggunakan sampel simple random sampling. Teknik pengumpulan data yang digunakan dalam penelitian ini adalah kuesioner (angket).Teknik analisis data dalam penelitian ini menggunakan analisa regresi ganda dengan tiga predictor.Dan uji analisis yang digunakan terdiri dari uji prasyarat dan uji hipotesis. Hasil penelitian ini menunjukkan bahwa (1) kompetensi pedagogik guru berpengaruh positif dan signifikan terhadap motivasi peserta didik kelas V SD di Kecamatan Jumo, (2) kompetensi profesional guru berpengaruh terhadap motivasi peserta didik kelas V SD di Kecamatan Jumo, dan (3) kompetensi pedagogik guru dan kompetensi profesional guru secara simultan (bersamasama) berpengaruh terhadap motivasi peserta didik kelas V SD di Kecamatan Jumo.
\end{abstract}

Kata Kunci: Kompetensipedagogik, kompetensi professional, motivation.

\begin{abstract}
This research aims to (1) analyze the effect of pedagogic competence on the learning motivation of fifth grade students in Jumo District, Temanggung Regency, (2) analyze the influence of professional competence on the learning motivation of fifth grade students in Jumo District, Temanggung Regency, and (3) analyze the effect of pedagogic and professional competence on the learning motivation of fifth grade students in Jumo District, Temanggung Regency. This type of research uses a quantitative research approach. The population in this study were all fifth grade elementary school students in Jumo District, Temanggung Regency in 2020/2021. The sample in this study used a simple random sampling sample. The data collection technique used in this research is a questionnaire (questionnaire). The data analysis technique in this study used multiple regression analysis with three predictors. And the analytical test used consists of prerequisite tests and hypothesis testing. The results of this study indicate that (1) teacher pedagogic competence has a positive and significant effect on the motivation of fifth grade elementary school students in Jumo District, (2) teacher professional competence affects the motivation of fifth grade elementary school students in Jumo District, and (3) pedagogic competence teachers and teacher professional competence simultaneously (together) affect the motivation of fifth grade elementary school students in Jumo District.
\end{abstract}

Keywords: pedagogic competence, professional competence, motivation.

Copyright (c) 2022 Krisnawati, Siti Yulaeha, Ketut Budiastra

$\triangle$ Corresponding author :

Email : krisnafreya@gmail.com

DOI : $\quad$ https://doi.org/10.31004/basicedu.v6i1.2181

ISSN 2580-3735 (Media Cetak)

ISSN 2580-1147 (Media Online)

Jurnal Basicedu Vol 6 No 1 Tahun 2022

p-ISSN 2580-3735 e-ISSN 2580-1147 
1117 Pengaruh Kompetensi Pedagogik dan Profesional Guru Terhadap Motivasi Belajar Peserta Didik Sekolah Dasar - Krisnawati, Siti Yulaeha, Ketut Budiastra

DOI: https://doi.org/10.31004/basicedu.v6i1.2181

\section{PENDAHULUAN}

Proses pembelajaran yang berkualitas, dapat dilihat ketika peserta didik dapat mengetahui, mengevaluasi dan menerapkan setiap ilmu yang didapat dari pembelajaran di kelas atau pengalamanpengalaman yang terjadi dalam kehidupan sehari-hari (Anggrelia, Tarbiyah, Keguruan, Negeri, \& Lampung, 2021). Guru dalam pembentukan proses pembelajaran yang berkualitas mempunyai peranan yang sangat penting, terlebih guru merupakan salah satu pendorong meningkatnya motivasi belajar siswa. Dalam penelitian yang dilakukan oleh Deputy chief program impact and policy save the children di Indonesia ada 646.000 sekolah ditutup selama pandemi Covid-19, dan membuat lebih dari 60 juta anak terdampak, 4 dari 10 atau 40 persen orang tua mengatakan motivasi belajar anak semakin berkurang (Raihan, 2021). Penyebab utama anak kehilangan motivasi belajar 70 persen disebabkan karena bosan, terlalu banyak tugas, metode belajar kurang menyenangkan, tidak ada interaksi, berebut fasilitas, perekonomian yang tidak merata, misalnya tidak setiap anak punya ponsel dan harus meminjam orang tua (Megandarisari, 2019).

Hasil tanya jawab dengan guru kelas V di Kecamatan Jumo tentang motivasi belajar peserta didik kelas V SD Negeri di Kecamatan Jumo. Di temukan permasalahan sebagai berikut: Peserta didik kurang tertarik mengikuti pembelajaran. Peserta didik duduk diam dan mendengarkan penjelasan guru tanpa adanya tanggapan. Peserta didik bergurau sendiri saat pelajaran (Padang \& Barat, 2019). Peserta didik untuk belajar harus diperintah tanpa ada kesadaran dari diri sendiri. Beberapa peserta didik mengerjakan PR di sekolah sebelum dikumpulkan (Suarni, Taufina, \& Zikri, 2019).

Rendahnya motivasi belajar peserta didik merupakan salah satu indikator dari kurangnya kemampuan guru dalam mengajar dan rendahnya minat peserta didik dalam kegiatan belajar (Sari, Taufina, \& Fachruddin, 2020). Itu artinya dalam belajar peserta didik belum memiliki keuletan dalam mempelajari materi pelajaran yang disampaikan oleh guru dan guru belum memberi pemberi pembelajaran yang menarik untuk peserta didik, agar mengoptimalkan kegiatan belajarnya dan peserta didik dapat belajar secara mandiri(Suarni et al., 2019).

Guru sebagai seseorang yang berwenang untuk mengajar dan mendidik peserta didik harus memiliki kualifikasi dan kompetensi yang baik agar upaya dalam mengkondisikan lingkungan belajar dapat merubah perilaku peserta didik menjadi lebih baik secara efektif dan efisien Djamarah (2000: 31-32). Guru yang berkualitas dapat ditinjau dari dua segi, yaitu segi proses dan segi hasil. Dari segi proses guru dikatakan berhasil apabila mampu melibatkan sebagian besar peserta didik secara aktif, baik fisik, mental,maupun sosial dalam proses pembelajaran (Padang \& Barat, 2019). Selain itu bisa dilihat dari gairah, semangat mengajarnya dan percaya diri. Sedangkan dari segi hasil, guru dikatakan berhasil apabila pembelajaran yang diberikannya mampu mengubah perilaku sebagian besar peserta didik ke arah penguasaan kompetensi dasar yang lebih baik Sardiman (2018:13).

Proses belajar mengajar merupakan inti dari proses pendidikan secara keseluruhan dan guru sebagai pemegang peranan utama dalam proses belajar mengajar (Julaeha, Hadiana, \& Zaqiah, 2021). Guru mempunyai tugas untuk mendorong, membimbing, dan memberi fasilitas belajar bagi peserta didik untuk mencapai tujuan (Masdiono, 2019). Penyampaian materi pelajaran hanyalah merupakan salah satu dari berbagai kegiatan dalam belajar sebagai suatu proses yang dinamis dalam segala fase dan proses perkembangan peserta didik Slameto (2003: 97).

Untuk dapat terlaksana dan suksesnya suatu kegiatan pembelajaran yang berkualitas, pertama harus ada dorongan atau motivasi untuk melaksanakan kegiatan tersebut, karena motivasi akan menyebabkan terjadinya suatu perubahan energi yang ada pada diri manusia, untuk kemudian bertindak atau melakukan sesuatu (Lubna, 2014). Semua ini didorong karena adanya tujuan, kebutuhan atau keinginan. Dengan kata lain, peserta didik perlu diberikan rangsangan agar tumbuh motivasi pada dirinya untuk mengikuti kegiatan belajar atau pendidikan yang sedang berlangsung. Sedangkan Yamin (2006:80) dalam bukunya strategi pembelajaran 
1118 Pengaruh Kompetensi Pedagogik dan Profesional Guru Terhadap Motivasi Belajar Peserta Didik Sekolah Dasar - Krisnawati, Siti Yulaeha, Ketut Budiastra

DOI: https://doi.org/10.31004/basicedu.v6i1.2181

berbasis kompetensi menjelaskan motivasi belajar merupakan daya penggerak psikis dari dalam diri seseorang untuk dapat melakukan kegiatan belajar dan menambah keterampilan dan pengalaman. Motivasi mendorong dan mengarah minat belajar untuk tercapainya suatu tujuan.

Atkinson dalam bukunya Hamzah (2011: 8) mengemukakan kecenderungan sukses ditentukan oleh motivasi, motivasi dipengaruhi oleh kecerdasan emosi seseorang. Dalam kegiatan belajar mengajar, peranan motivasi baik intrinsik maupun ekstrinsik sangat diperlukan. Guru yang kompeten akan lebih mampu menciptakan lingkungan belajar yang efektif, menyenangkan, dan lebih mampu mengelola kelasnya sehingga proses belajar para peserta didik dapat berjalan dengan baik dan lancar (Suyitno, 2009).

Kualitas proses pembelajaran membutuhkan pengembangan sumber daya manusia pendidik, khususnya pengembangan kompetensi guru. Menurut Undang-Undang Nomor 14 Tahun 2005 pasal 10 ayat 1 dan penjelasannya, Kompetensi tersebut meliputi: (1) kompetensi pedagogik yaitu kemampuan dalam pengelolaan peserta didik, (2) kompetensi kepribadian yaitu kemampuan berkepribadian, (3) kompetensi profesional yaitu kemampuan penguasaan materi pembelajaran secara luas dan mendalam, (4) kompetensi sosial yaitu kemampuan pendidik sebagai bagian dari masyarakat. Kompetensi pedagogik dan kompetensi profesional merupakan dua dari empat kompetensi yang harus dimiliki guru. Dengan kompetensi pedagogik apa yang dilakukan, dilaksanakan dan dihasilkan guru di sekolah, dapat dipertanggung jawabkan kebenaran dan objektivitas-nya. Sedangkan dengan kompetensi profesional guru akan mampu menilai kemampuan peserta didiknya dalam memahami materi sebagai bentuk capaian hasil belajar (Afriyanti, 2015).

Melalui pengamatan dan hasil catatan kepala sekolah saat melaksanakan penilaian kinerja guru (PKG) kompetensi pedagogik dan kompetensi profesional guru kelas $\mathrm{V}$ mempunyai kemampuan yang berbeda beda. Dari catatan tersebut ditemukan beberapa masalah yang berkaitan dengan kompetensi pedagogik dan kompetensi profesional guru. Berikut ini temuan masalah yang berkaitan dengan kompetensi pedagogik. Satu guru dalam pembelajaran masih menggunakan metode ceramah belum menggunakan metode yang dialogis dan interaktif. Dua guru menggunakan perangkat pembelajaran yang sudah ada tanpa disesuaikan dengan lingkungan sekolah. Tiga guru kurang melibatkan peserta didik dan pembelajaran bersifat searah. Sedangkan masalah yang berkaitan dengan kompetensi profesional diantaranya Guru belum mengembangkan materi pelajaran yang diampu secara kreatif. Guru belum melaksanakan PTK berkaitan masalah di kelasnya. Guru dalam mengajar belum memanfaat teknologi.Menurut Indriyani (2016) motivasi adalah dorongan yang menyebabkan terjadinya suatu perbuatan guna mencapai suatu tujuan. Yang dimaksud motivasi dalam hal ini adalah motivasi belajar, yaitu suatu dorongan atau kemauan seseorang untuk melakukan aktivitas belajar agar prestasi belajar dapat dicapai.Kompetensi guru adalah kecakapan atau kemampuan dasar kognitif, afektif, dan psikomotorik seorang guru yang meliputi pengetahuan, pemahaman kemampuan, nilai, sikap dan minta yang harus dimiliki guru untuk mendukung dan melaksanakan tugas dan tanggung jawabnya. Pedagogik diartikan dengan ilmu mendidik, yang lebih menitik beratkan kepada pemikiran perenungan tentang pendidikan atau suatu pemikiran bagaimana membimbing anak, dan mendidik anak, (Sadulloh, 2011). Kompetensi professional adalah kemampuan penguasaan materi pembelajaran secara luas dan mendalam yang memungkinkan membimbing peserta didik memenuhi standar kompetensi yang ditetapkan dalam Standar Nasional Pendidikan.

\section{METODE}

Jenis penelitian ini menggunakan pendekatan penelitian kuantitatif. Penelitian kuantitatif adalah metode penelitian yang berlandaskan positivisme digunakan untuk meneliti pada populasi dan sampel tertentu. Penelitian ini dilaksanakan pada peserta didik kelas V di wilayah Kecamatan Jumo yang berjumlah 17 sekolah yaitu SDN Padureso, SDN Sukomarto, SDN Karangtejo, SDN Morobonggo dan SDN Barang. SDN 1 Ketitang, SDN 2 Ketitang, SDN 1 Jombor, SDN 2 Jombor, SDN Giyono, SDN 1 Kertosari, SDN 2 Kertosari, 
1119 Pengaruh Kompetensi Pedagogik dan Profesional Guru Terhadap Motivasi Belajar Peserta Didik Sekolah Dasar - Krisnawati, Siti Yulaeha, Ketut Budiastra

DOI: https://doi.org/10.31004/basicedu.v6i1.2181

SDN Gunung Gempol, SDN Jumo,SDN Jamusan, SDN 1 Gedongsari, SDN 2 Gedongsari. Waktu penelitian ini dilaksanakan pada bulan Agustus - November 2020, tahun pelajaran 2020/2021.Populasi pada penelitian ini adalah seluruh peserta didik kelas V SD di Kecamatan Jumo Kabupaten Temanggung Tahun 2020/2021. Sampel dalam penelitian ini menggunakan sampel simple random sampling. Instrumen yang digunakan dalam penelitian ini adalah angket. Teknik analisis data untuk penelitian ini adalah sebagai berikut: Uji deskriptif statistic, Uji prasyarat analisis, dan Uji hipotesis (uji t dan uji f).

\section{HASIL DAN PEMBAHASAN}

\section{Pengaruh Kompetensi pedagogik guru terhadap Motivasi peserta didik (Hipotesis 1)}

Untuk dapat terlaksana dan suksesnya suatu kegiatan pembelajaran yang berkualitas, pertama harus ada dorongan atau motivasi untuk melaksanakan kegiatan pembelajaran. Dorongan atau motivasi tidak hanya dari guru tetapi bisa juga dorongan dari peserta didik dan keluarga.

Kompetensi pedagogik merupakan kemampuan yang berkaitan dengan pemahaman peserta didik dan pengelola pembelajaran yang mendidik dan dialogis. Secara substansi, kompetensi ini mencakup kemampuan pemahaman terhadap peserta didik, perancangan dan pelaksanaan pembelajaran, evaluasi hasil belajar, dan pengembangan peserta didik untuk mengaktualisasikan berbagai potensi yang dimilikinya (Pratiwi, 2015) sedangkan motivasi belajar menurut sardiman ( 2018: 73) adalah dorongan dalam kegiatan belajar, sehingga motivasi dapat dikatakan sebagai daya penggerak dalam diri peserta didik yang menimbulkan kegiatan belajar supaya tujuan yang dikehendaki oleh subjek belajar itu dapat dicapai.

Berdasarkan hasil penelitian diketahui bahwa kompetensi pedagogik guru berpengaruh terhadap motivasi peserta didik kelas V SD di Kecamatan Jumo, hal ini berdasar hasil analisis regresi linier sederhana pada uji $t$ yang didapat nilai nilai $t_{\text {hitung }}>\mathrm{t}_{\text {tabel }}(12,351>2,10982)$ atau signifikansi $<0,05(0,000<0,05)$, sehingga Ho ditolak dan Ha diterima. Dengan demikian hipotesis pertama yang menyatakan "Kompetensi pedagogik guru berpengaruh terhadap motivasi peserta didik kelas V SD di Kecamatan Jumo" terbukti dan dapat dinyatakan diterima. Adapun besarnya pengaruh variabel kompetensi pedagogik terhadap variabel motivasi adalah sebesar 12,94\%.

Faktor - faktor yang mempengaruhi motivasi belajar peserta didik sangatlah banyak, diantaranya faktor-faktor yang mempengaruhi motivasi belajar menurut Brownlee (2006) adalah pertama faktor guru, guru tidak cukup tahu sesuatu materi yang akan diajarkan, tetapi pertama kali ia harus merupakan seseorang yang memang memiliki kepribadian guru dengan segala ciri tingkat kedewasaannya dan memiliki kepribadian. Kedua faktor orang tua, faktor orang tua dalam keluarga sangat menentukan juga karena mereka adalah mitra para guru dalam bekerja bersama-sama untuk tujuan tersebut. Orang tua tidak cukup puas hanya menyerahkan urusan dan tanggung jawab ini pada guru. Ketiga faktor lingkungan masyarakat, faktor lingkungan masyarakat tempat berdomisili peserta didik menjadi unsur yang turut dipetimbangkan dalam proses pembentukan motivasi peserta didik, karena peserta didik juga adalah bagian ataupun warga dari suatu masyarakat.

Penelitian ini dilakukan di masa pandemik covid 19, Salah satu dampak pandemi covid 19 menerpa di bidang pendidikan. Sejak ditetapkan sebagai bencana nasional, pemerintah Indonesia melalui menteri Pendidikan Nasional membuat kebijakan pendidikan melalui tatap muka menjadi pembelajaran di rumah. Artinya kegiatan belajar mengajar yang biasanya dilakukan di sekolah menjadi di rumah. Saat belajar dirumah guru hanya memberikan panduan dan materi yg akan dipelajari peserta didik. Orang tua yang menindak lanjuti dan mengawasi anak dalam belajar, sehingga selain faktor kompetensi pedagogik mempengaruh motivasi belajar peserta didik tetapi ada faktor lain yang memotivasi peserta didik dalam belajar yaitu bisa faktor orang tua dan faktor lingkungan tempat tinggal peserta didik. 
1120 Pengaruh Kompetensi Pedagogik dan Profesional Guru Terhadap Motivasi Belajar Peserta Didik Sekolah Dasar - Krisnawati, Siti Yulaeha, Ketut Budiastra

DOI: https://doi.org/10.31004/basicedu.v6i1.2181

\section{Pengaruh Kompetensi profesional guru terhadap Motivasi peserta didik (Hipotesis 2)}

Menurut Undang-undang No. 14 tahun 2005 tentang guru dan dosen, kompetensi profesional adalah kemampuan penguasaan materi pembelajaran secara luas dan mendalam yang memungkinkannya membimbing peserta didik memenuhi standar kompetensi yang ditetapkan dalam Standar Nasional Pendidikan. Kompetensi profesional meliputi kepakaran atau keahlian dalam bidangnya yaitu penguasaan bahan yang harus diajarkan beserta metode, rasa tanggung jawab akan tugasnya dan rasa kebersamaan dengan sejawat guru lainya. Peran dari kompetensi profesional guru menyesuaikan perencanaan dan pelaksanaan dalam proses pembelajaran agar pembelajaran aktif, efektif, dan efisien sehingga melahirkan sistem pembelajaran bermutu yang mencerdaskan. Analisis pengaruh kompentensi pedagogik (X1) terhadap motivasi belajar peserta didik (Y) sebagaimana terlihat padatabelberikut :

Tabel 1 Hasil uji regresi sederhana X1 terhadap Y

\begin{tabular}{|c|c|c|c|c|c|c|}
\hline \multirow{2}{*}{\multicolumn{2}{|c|}{ Model }} & $\begin{array}{r}\text { Unstand } \\
\text { Coeffi }\end{array}$ & $\begin{array}{l}\text { lized } \\
\text { nts }\end{array}$ & $\begin{array}{l}\text { Standardi } \\
\text { zed } \\
\text { Coefficie } \\
\text { nts }\end{array}$ & \multirow[b]{2}{*}{$\mathrm{t}$} & \multirow[b]{2}{*}{ Sig. } \\
\hline & & \multicolumn{3}{|c|}{ Std. } & & \\
\hline 1 & $\begin{array}{l}\text { (Constant } \\
\text { ) }\end{array}$ & 74.517 & 6.033 & & 12.351 & 0.000 \\
\hline & $\mathrm{X} 1$ & 0.049 & 0.138 & 0.092 & 0.357 & 0.726 \\
\hline
\end{tabular}

a. Dependent Variable: $\mathrm{Y}$

Sumber: Data diolah tahun 2021 menggunakan SPSS 26

Dari tabel 1 nilai $t$ tabel $(\alpha, d b)=t(0,05,17)=2,10982$ dari hasil uji regresi sederhana di atas dipeoleh $t_{\text {hitung }}=12,351 \mathrm{Sig}$ (2-tailed) sebesar 0,000 . Ini artinya $t_{\text {hitung }} \geq t_{\text {tabel }}$ yaitu $12,351 \geq 2,10982$ dan nilai Sig (2tailed) $0,000<0,05$ maka uji hipotesis ini adalah kompetensi pedagogik guru tidak berpengaruh terhadap motivasi belajar peserta didik ( Ho) ditolak dan kompetensi pedagogik berpengaruh terhadap motivasi belajar peserta didik ( Ha) diterima, itu artinya terdapat pengaruh yang signifikan antara kompetensi pedagogik (X1) terhadap motivasi belajar peserta $\operatorname{didik}(\mathrm{Y})$.

Berdasarkan hasil penelitian diketahui bahwa Kompetensi profesional guru berpengaruh terhadap motivasi peserta didik kelas V SD di Kecamatan Jumo, hal ini berdasar hasil analisis regresi linier berganda pada uji $t$ yang didapat nilai nilai $t_{\text {hitung }}>t_{\text {tabel }}(4,110>2,10982)$ atau signifikansi $<0,05(0,001<0,05)$, sehingga Ho ditolak dan Ha diterima. Nilai t hitung positif artinya berpengaruh positif, yaitu jika Kompetensi profesional guru meningkat maka motivasi peserta didik juga meningkat.

Dengan demikian hipotesis kedua yang menyatakan "Kompetensi profesional guru berpengaruh terhadap Motivasi peserta didik kelas V SD di Kecamatan Jumo" terbukti dan dapat dinyatakan diterima. Adapun besarnya pengaruh variabel kompetensi profesional terhadap variabel motivasi adalah sebesar 9,07\%.Berpengaruhnya kompetensi profesional terhadap motivasi peserta didik dikarenakan guru yang memiliki kompetensi profesional akan mengetahui karakteristik dari karakteristik dari peserta didik,sehingga dalam membuat perangkat pembelajaran guru disesuaikan dengan karakteristik serta kemampuan peserta didik. Di masa pandemik covid 19 guru yang profesional akan memanfaatkan teknologi yang ada untuk tetap melakukan pembelajaran dengan peserta didiknya. 
1121 Pengaruh Kompetensi Pedagogik dan Profesional Guru Terhadap Motivasi Belajar Peserta Didik Sekolah Dasar - Krisnawati, Siti Yulaeha, Ketut Budiastra

DOI: https://doi.org/10.31004/basicedu.v6i1.2181

\section{Pengaruh Kompetensi pedagogik guru dan Kompetensi profesional guru terhadap Motivasi peserta didik (Hipotesis 3)}

Kompetensi guru adalah kecakapan atau kemampuan dasar kognitif, afektif, dan psikomotorik seorang guru. Yang meliputi pengetahuan, pemahaman kemampuan, nilai, sikap dan minta yang harus dimiliki guru untuk mendukung dan melaksanakan tugas dan tanggung jawabnya (Pratiwi, 2015). Menurut Wibowo (2012, 30) mengungkapkan bahwa terdapat beberapa faktor yang mempengaruhi kompetensi guru, yaitu: satu, nilainilai keyakinan orang tentang dirinya maupun terhadap orang lain akan sangat mempengaruhi perilaku. Apabila orang percaya bahwa mereka tidak kreatif dan inovatif, mereka tidak akan berusaha berpikir tentang cara baru atau berbeda dalam melakukan sesuatu. Dua, keterampilan dengan memperbaiki keterampilan individu akan meningkatkan kecakapannya dalam kompetensi. Ketiga, pengalaman keahlian dari banyak kompetensi memerlukan pengalaman. Diantaranya pengalaman dalam mengorganisasi orang, komunikasi didepan kelompok, menyelesaikan masalah dan sebagainya. Empat, karakteristik kepribadiankepribadian bukanlah sesuatu yang tidak dapat berubah. Kepribadian seseorang dapat berubah sepanjang waktu. Orang merespon dan berinteraksi dengan kekuatan dan lingkungan sekitar. Lima, motivasi dengan memberikan dorongan, apresiasi terhadap pekerjaan seseorang, memberikan pengakuan dan perhatian individual dari atasan dapat memberikan pengaruh positif terhadap motivasi seseorang. Enam, isu emosional / hambatan emosional dapat membatasi penguasaan kompetensi. Misal, takut membuat kesalahan, menjadi malu, merasa tidak disukai atau tidak menjadi bagian, semuanya cenderung membatasi motivasi dan inisiatif. Tujuh, kemampuan intelektual kompetensi tergantung pada pemikiran kognitif seperti pemikiran analisis dan pemikiran konseptual. Delapan, budaya organisasi.

Berdasarkan hasil penelitian diketahui bahwa kompetensi pedagogik guru dan kompetensi profesional guru secara bersama-sama berpengaruh terhadap motivasi peserta didik kelas V SD Kecamatan Jumo, hal ini berdasar hasil analisis regresi linier berganda pada uji $\mathrm{F}$ yang didapat nilai $\mathrm{F}$ hitung $>\mathrm{F}$ tabel $(8,811>3,59)$ atau signifikansi $<0,05(0,003<0,05)$, sehingga Ho ditolak dan Ha diterima. Dengan demikian hipotesis kedua yang menyatakan "Kompetensi pedagogik guru dan Kompetensi profesional guru secara bersama-sama berpengaruh terhadap motivasi belajar peserta didik kelas V SD di Kecamatan Jumo, terbukti dan dapat dinyatakan diterima. Adapun besarnya pengaruh variable kompetensi pedagogik dan kompetensi professional secara simultan terhadap variabel motivasi adalah sebesar $22,0 \%$.

\section{KESIMPULAN}

Kompetensi pedagogik guru berpengaruh positif dan signifikan terhadap motivasi peserta didik kelas $\mathrm{V}$ SD di Kecamatan Jumo. Hal ini berdasar hasil uji $t$ yang didapat nilai $t_{\text {hitung }}>t_{\text {tabel }}(12,351>2,10982)$ atau signifikansi $<0,05(0,000<0,05)$, sehingga Ho ditolak dan Ha diterima, dengan besarnya pengaruh variabel kompetensi terhadap variabel motivasi sebesar 12, $94 \%$. Kompetensi profesional guru berpengaruh terhadap motivasi peserta didik kelas V SD di Kecamatan Jumo. Hal ini berdasar hasil uji t yang didapat nilai $t_{\text {hitung }}>$ $\mathrm{t}_{\text {tabel }}(4,110>2,10982)$ atau signifikansi $<0,05(0,001<0,05)$, sehingga Ho ditolak dan Ha diterima, dengan besarnya pengaruh variabel kompetensi terhadap variabel motivasi sebesar 9,07\%.Kompetensi pedagogik guru dan kompetensi profesional guru secara simultan (bersama-sama) berpengaruh terhadap motivasi peserta didik kelas V SD di Kecamatan Jumo. Hal ini berdasar hasil uji $\mathrm{F}$ yang didapat nilai $\mathrm{F}_{\text {hitung }}>\mathrm{F}_{\text {tabel }}(8,811>$ $0,003)$ atau signifikansi $<0,05(0,003<0,05)$, sehingga Ho ditolak dan Ha diterima dengan besarnya pengaruh secara simultan adalah sebesar $22,0 \%$. 
1122 Pengaruh Kompetensi Pedagogik dan Profesional Guru Terhadap Motivasi Belajar Peserta Didik Sekolah Dasar - Krisnawati, Siti Yulaeha, Ketut Budiastra

DOI: https://doi.org/10.31004/basicedu.v6i1.2181

\section{DAFTAR PUSTAKA}

Anggrelia, T., Tarbiyah, F., Keguruan, D. A. N., Negeri, U. I., \& Lampung, R. I. (2021). Pengembangan Media Pembelajaran Pada Pembelajaran Tematik Tema 8 Pada Pembelajaran.

Abidin, Z., Priadi, M.D., Setiawati, E., Yanti, D., \& Purwanto, A. (2020). Effect Of Pedagogic, Professional Competency, And Work Motivation Toward Indonesian Primary School Teachers Performance.

Afriyanti, M. (2015). Pengaruh Kompetensi Pedagogik Terhadap Kinerja Guru Sekolah Dasar Gugus Sadewa Dan Bima Kecamatan Kutowikngun Kabupaten Kebumen . Semarang :Doctoral Dissertation, Universitas Negeri Semarang.

Andriani, E. (2017). Pengaruh Kompetensi Pedagogik Terhadap Kinerja Guru Sekolah Dasar Negeri Dabin II Kecamatan Petarukan Kabupaten Pemalang. Semarang: Doctoral Dissertation, Universitas Negeri Semarang.

Arikunto, Suharsimi. (2006). Prosedur Penelitian Suatu Pendekatan Praktik. Jakarta: Rineka Cipta.

Darmawati, J. (2017). Pengaruh Motivasi Belajar Dan Gaya Belajar Terhadap Prestasi Belajar Ekonomi Peserta Didik SMA Negeri Di Kota Tuban. Jurnal Ekonomi Pendidikan Dan Kewirausahaan, 1(1), 7990.

Departemen Pendidikan Nasional. (2003). Naskah Akademik Sertifikasi Kompetensi Tenaga Kependidikan.

Departemen Pendidikan Nasional. (2005). Peraturan Pemerintah Nomor 19 Tahun 2005 Tentang Standar Nasional Pendidikan.

Departemen Pendidikan Nasional. (2007). Permendiknas Nomor 16 Tahun 2007 Tentang Standar Kompetensi Guru.

Departemen Pendidikan Nasional. (2006). Undang - Undang Republik Indonesia Nomor 14 Tahun 2005 Tentang Guru Dan Dosen.

Departemen Pendidikan Nasional. (2009). Permenneg PAN Dan RB No.16 Tahun 2009 Pasal 15 Tentang Jabatan Fungsional Guru Dan Angka Kreditnya.

Dimyati, (2009). Belajar Dan Pembelajaran. Jakarta: Rineka Cipta.

Djamarah, Syaiful Bahri. (2000). Guru Dan Anak Didik Dalam Interaksi Edukatif. Jakarta: Rineka Cipta.

Effendy, A. (2019). Pengaruh Kompetensi Guru Dan Budaya Sekolah Terhadap Prestasi Belajar Peserta Didik Sebagai Acuan Peningkatan Layanan Pendidikan Di SMA Al Izzah Batu. Malang: Doctoral Dissertation, University Of Muhammadiyah Malang.

Firmansyah, D. (2015). Pengaruh Strategi Pembelajaran Dan Minat Belajar Terhadap Hasil Belajar Matematika. Judika (Jurnal Pendidikan UNSIKA), 3(1).

Fitria, R. (2016). Pengaruh Kompetensi Guru Dan Iklim Organisasi Terhadap Kinerja Guru Pendidikan Agama Islam Sekolah Dasar Di Kecamatan Gunung Talang Kabupaten Solok. Al-Fikrah. Jurnal Manajemen Pendidikan, 2(2), 169-176.

Ghozali, Imam. (2013). Aplikasi Analisis Multivariate Dengan Program SPSS. Semarang: Badan Penerbit Universitas Diponegoro.

Hamzah B. Uno. (2011). Teori Motivasi Dan Pengukurannya: Analisis Di Bidang

Pendidikan. Jakarta: Bumi Aksara.

Hamzah B. Uno. (2012). Model Pembelajaran Menciptakan Proses Belajar Mengajar Yang Kreatif Dan Efektif. Jakarta: PT. Bumi Aksara.

Hanifuddin, Jamin. (2018). Upaya Meningkatkan Kompetensi Profesional Guru At-Ta'dib. Jurnal Ilmiah Pendidikan Agama Islam Volume 10, No. 1, Juni 2018.

Heriswanto, H. (2018). Pengaruh Kompetensi Guru Terhadap Kinerja Guru SMPN Ilambuya Kab. Konawe 
1123 Pengaruh Kompetensi Pedagogik dan Profesional Guru Terhadap Motivasi Belajar Peserta Didik Sekolah Dasar - Krisnawati, Siti Yulaeha, Ketut Budiastra

DOI: https://doi.org/10.31004/basicedu.v6i1.2181

Melalui Motivasi Kerja Sebagai Variabel Intervening. Aksara Public, 2(3), 136-152.

Indra, S. (2016). Pengaruh Kompetensi Pada Peserta Didik Di SMK Farmako Medika Plus Caringin-Bogor. Surakarta: Doctoral Dipssertation, IAIN Surakarta.

Indriani, A. (2016). Pengaruh Motivasi Belajar Peserta Didik Kelas V Terhadap Repstasi Belajar Matematika Di SD Negeri Bejirejo Kecamatan Kunduran Kabupaten Blora. JIPM (Jurnal Ilmiah Pendidikan Matematika), 4(2), 134-139.

Julaeha, S., Hadiana, E., \& Zaqiah, Q. Y. (2021). Manajemen Inovasi Kurikulum: Karakteristik Dan Prosedur Pengembangan Beberapa Inovasi Kurikulum. MUNTAZAM: Jurnal Manajemen Pendidikan Islam, 2(01), 1-26. Retrieved From Https://Journal.Unsika.Ac.Id/Index.Php/Muntazam/Article/View/5338.

Kuswanto, H., Halim, A., \& Priyastiwi, P. (2019). Analisis Kompetensi Guru Di SMP Negeri 1 Bansari Kabupaten Temanggung Tahun 2018. Yogyakarta: Doctoral Dissertation, STIE Widya Wiwaha.

Lestari, I. (2015). Pengaruh Waktu Belajar Dan Minat Belajar Terhadap Hasil Belajar Matematika. Formatif: Jurnal Ilmiah Pendidikan MIPA, 3(2).

Lubna, L. (2014). Isu-Isu Pendidikan Di Indonesia: Inovasi Kurikulum Dan Peningkatan Profesionalitas Guru. SOCIETY, Vol 12, No 2 (2014).

Masdiono, M. (2019). Desain Pengembangan Kurikulum Pendidikan Dasar. Bada'a: Jurnal Ilmiah Pendidikan Dasar, 1(1), 44-53. Https://Doi.Org/10.37216/Badaa.V1i1.243.

Megandarisari. (2019). Adaptasi Kurikulum Pendidikan Anak Usia Dini Di Masa Pandemi Covid-19. Jurnal Inovasi Kurikulum, 5(2), 105-123.

Mulyasa, E. (2016). Menjadi Guru Profesional. Bandung: Remaja Rosdakarya.

Nana, Sudjana. (2009). Penilaian Hasil Proses Belajar Mengajar. Bandung: PT Remaja Rosdakarya.

Nefida, Eri. (2016). Peran Kompetensi Profesional Dan Pedagogik Terhadap Prestasi Belajar Bahasa Inggris SMA 1 Lupuk Sikeping. Jakarta: Masther Thesis. Universitas Terbuka.

Notoatmodjo, S. (2010). Metodologi Penelitian Kesehatan. Jakarta: Rineka Cipta

Nurdianti, R. R. S. (2017). Pengaruh Kompetensi Profesional Dan Kompetensi Pedagogik Terhadap Kinerja Guru Ekonomi SMA Negeri Di Kota Bandung. Jurnal Ilmiah Manajemen Dan Bisnis, 18(2), 177-188.

Nurdyansyah, N., \& Fitriyani, T. (2018). Pengaruh Strategi Pembelajaran Aktif Terhadap Hasil Belajar Pada Madrasah Ibtidaiyah. Jurnaluniversitas Muhammadiyah Sidoarjo.

Padang, U. N., \& Barat, S. (2019). Bercerita Di Sekolah Dasar, 3(4), 1022-1030.

Priansa, Donni Juni. (2014). Kinerja Dan Profesionalisme Guru. Bandung: Alfabeta.

Priyanto, Dwi. (2014). SPSS 26: Pengolahan Data Terpraktis.Yogyakarta: Andi Offset.

Raihan, S. (2021). Implementasi Workshop Blended Learning Menggunakan E-Book Lesson Plan Berbasis Hypercontent Dalam Meningkatkan Kompetensi Guru. Publikasi Pendidikan, 11(1), 57. Https://Doi.Org/10.26858/Publikan.V11i1.19075.

Sari, L., Taufina, T., \& Fachruddin, F. (2020). Pengembangan Lembar Kerja Peserta Didik (LKPD) Dengan Menggunakan Model PJBL Di Sekolah Dasar. Jurnal Basicedu, 4(4), 813-820. Https://Doi.Org/10.31004/Basicedu.V4i4.434.

Suarni, N., Taufina, T., \& Zikri, A. (2019). Literasi Membaca Meningkatkan Karakter Positif Siswa Sekolah Dasar. Jurnal Basicedu, 3(4), 1014-1021. Https://Doi.Org/10.31004/Basicedu.V3i4.215.

Suyitno, Y. (2009). Oleh: Pengertian Dan Permasalahan-. Landasan Filosofis Pendidikan. Retrieved From Http://File.Upi.Edu/Direktori/FIP/Jur._Pedagogik/195009081981011-

Y._Suyitno/Landasan_Filosofis_Pendidikan_Dasar.Pdf.

Sadirman A. M. (2018). Interaksi Dan Motivasi Belajar Mengajar. Depok: PT Rajagrafindo Persada. 
1124 Pengaruh Kompetensi Pedagogik dan Profesional Guru Terhadap Motivasi Belajar Peserta Didik Sekolah Dasar - Krisnawati, Siti Yulaeha, Ketut Budiastra

DOI: https://doi.org/10.31004/basicedu.v6i1.2181

Sagala, (2013). Kemampuan Profesional Guru Dan Tenaga Kependidikan. Bandung: Alfabeta.

Salsabila, T., \& Usman, O. (2021). Influence Of Student Motivation, Student Learning Facilities And Lecturer Teaching Skills Towards Learning Interest. SSRN Electronic Journal.

Setyosari, Punaji. (2015). Metode Penelitian Pendidikan Dan Pengembangan Edisi Ke Empat. Jakarta: Prenadamedia Group.

Shalahuddin, Mahfudh. (1998). Pengantar Psikologi Pendidikan. Surabaya: Bina Ilmu.

Slameto. (2010). Belajar Dan Faktor- Faktor Yang Mempengaruhinya. Jakarta: Pustaka Indonesia

Sopandi, A. (2019). Pengaruh Kompetensi Profesional Dan Kompetensi Kepribadian Terhadap Kinerja Guru. Scientific Journal Of Reflection: Economic, Accounting, Management And Business, 2(2), 121-130.

Sugiyono. (2015). Metode Penelitian Kuantitati, Kualitatif Dan R\&D. Bandung: Alfabeta.

Sulfemi, W. B., \& Minati, H. (2018). Meningkatkan Hasil Belajar Peserta Didik Kelas 3 SD Mmnggunakan Model Picture And Picture Dan Media Gambar Seri. Jpsd (Jurnal Pendidikan Sekolah Dasar), 4(2), 228242.

Suryabrata, Sumadi. (2002). Psikologi Pendidikan. Jakarta: PT. Grafindo Perkasa Rajawali.

Supardi. (2013). Kinerja Guru. Jakarta: PT. Raja Grafindo Persada.

Suprihatiningrum, Jamil. (2013). Guru Profesional: Pedoman Kinerja, Kualifikasi, \& Kompetensi Guru. Yogyakarta: Ar-Ruzz Media.

Wibowo. (2011). Manajemen Kinerja. Jakarta: PT Raja Grafindo Persada.

Yamin, Martinis. (2006). Strategi Pembelajaran Berbasis Kompetensi. Jakarta:

Gaung Persada Press.

Yilmaz, R. (2017). Exploring The Role Of E-Learning Readiness On Student Satisfaction And Motivation In Flipped Classroom. Comput. Hum. Behav., 70, 251-260. 